\title{
Is high AgNOR quantity in hepatocytes associated with increased risk of hepatocellular carcinoma in chronic liver disease?
}

\author{
M Derenzini, D Trerè, F Oliveri, E David, P Colombatto, F Bonino, M R Brunetto
}

\begin{abstract}
Aims-To evaluate whether high numbers of silver staining nucleolar organiser regions (AgNORs) in hepatocytes are associated with increased risk of hepatocellular carcinoma in chronic liver disease.

Methods-The quantitative distribution of AgNORs was studied in the liver biopsy specimens of 33 patients with chronic liver disease, 11 of whom developed hepatocellular carcinoma. The interval between liver biopsy and diagnosis of hepatocellular carcinoma was 26 months (range one to 61 months); the mean follow up of patients without hepatocellular carcinoma was 45 months (range 24-59 months). Quantitative evaluation of AgNORs was carried out on silver stained routine sections by morphometric analysis, using a computer assisted image analysis system.

Results-High interphase AgNOR values $\left(>3 \mu \mathrm{m}^{2}\right)$ were found in hepatocytes of nine out of the $11(82 \%)$ patients in whom neoplastic transformation occurred. Of the remaining 22 patients, only seven (31\%) had AgNOR values higher than $>3$ $\mu \mathrm{m}^{2}\left(\chi^{2} 4.83 ; \mathrm{p}=0.036\right)$.

Conclusions-These results indicate that high numbers of interphase AgNORs are associated with increased risk of hepatocellular carcinoma in patients with chronic liver disease.
\end{abstract}

$(\mathcal{F}$ Clin Pathol 1993;46:727-729)

Hepatocellular carcinoma is the fourth commonest cause of death from neoplasia in the world (250 000 cases a year). ${ }^{1}$ It is frequently associated with chronic liver diseases such as cirrhosis and chronic hepatitis, and the duration of cirrhosis and necroinflammation are considered to be major risk factors. Surgical resection or medical treatment can improve survival, although patients with hepatocellular carcinoma must be diagnosed sufficiently early to benefit from these forms of treatment. ${ }^{2}$ Predictive tests are therefore mandatory for the screening of patients with chronic liver disease.

In experimental hepatocarcinogenesis intermediate non-cancerous lesions, characterised by a progressive increase of hepatocyte proliferative activity, precede the onset of cancer. ${ }^{3}$ Tanaka et al correlated the proliferative activity of hepatocellular carcinoma induced by $\mathrm{N}-2$-Fluorenylacetamide with the mean number of silver stained interphase nucleolar organiser regions (AgNORs) in hepatocyte nuclei. ${ }^{4}$ Interphase NORs are nucleolar components containing ribosomal genes associated with a group of argyrophilic proteins. ${ }^{56}$ Evidence suggests that the numbers of interphase AgNORs are directly related to cell proliferation rate. A strict correlation was in fact observed between interphase AgNOR values and the percentage of S-phase cells, determined by either DNA flow cytometry or bromodeoxyuridine (BrdU) incorporation, in non-Hodgkin's lymphomas, ${ }^{7}$ breast tumours, ${ }^{8}$ and meningiomas. ${ }^{9}$ Interphase AgNOR numbers and cell proliferative indices, evaluated by BrdU labelling and $\mathrm{Ki}-67$ immunostaining, were also found to be directly related in cancer tissues of different origin. ${ }^{10} \mathrm{~A}$ linear relation between interphase AgNOR number and rapidity of cell proliferation has also been shown. ${ }^{11} 12$

We studied the correlation between the hepatocyte proliferation rates, determined by AgNOR quantitative evaluation, and the risk of hepatocellular carcinoma in patients with chronic liver disease followed up for 15 to 74 months after the liver biopsy.

\section{Methods}

The liver biopsy specimens of 33 patients with chronic liver disease were studied retrospectively. Eleven subsequently developed hepatocellular carcinoma during follow up at the Department of Gastroenterology, Molinette Hospital, Turin, between 1985 and 1992. The interval between the liver biopsy and diagnosis of hepatocellular carcinoma was 26 months (range one to 61 months), while the mean follow up of patients without hepatocellular carcinoma was 45 months (range 24-59 months). There was no significant difference between the two groups regarding sex, sociodemographic features, and severity of liver disease. The median age of the patients with hepatocellular carcinoma (59 years, range 23-69 years) was higher than that of patients without hepatocellular carcinoma ( 43.5 years, range $28-64$ years).

The level of intrahepatic inflammation was determined by the method of Knodell and coworkers. ${ }^{13}$

Cell kinetic analysis was performed by measuring the interphase AgNOR numbers on routine histological sections of 33 liver biopsy specimens stained by the silver method according to Ploton and coworkers. ${ }^{14}$ 


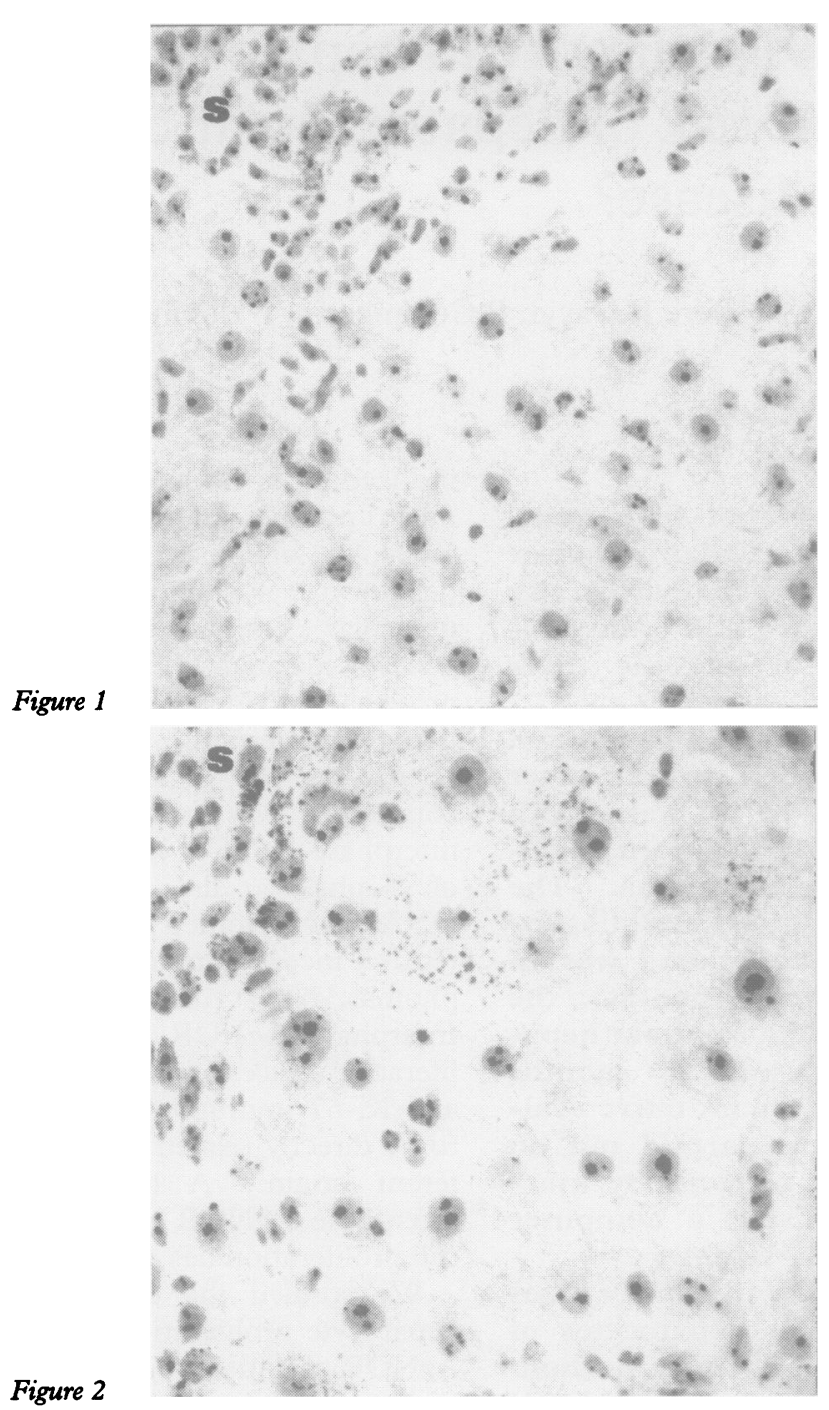

AgNOR staining of liver from two patients with chronic liver disease, one of whom (figure 2) developed hepatocellular carcinoma. Note the higher quantity of silver stained nucleolar structures in the hepatocytes of figure 2 compared with those in figure 1. S: stromal and inflammatory cells.

All the specimens had been fixed in buffered formalin. NOR silver staining was carried out using a solution of one volume $2 \%$ gelatine in $1 \%$ aqueous formic acid and two volumes of $50 \%$ silver nitrate. The staining reaction was performed for 14 minutes at $37^{\circ} \mathrm{C}$.

The area occupied by the interphase AgNORs within nuclei of 100 cells a patient was measured using a specific program (IM 5200) of a computer assisted image analysis system (Sistema MONO, Immagini e Computer, Milan).

Statistical analysis of measured data was performed using the $\chi^{2}$ test and Fisher's exact test. Statistical significance was defined at $\mathrm{p}<0.05$.

\section{Results}

The mean AgNOR areas of the 33 cases evaluated ranged from 2.01 to $7.42 \mu \mathrm{m}^{2}$ (table). AgNOR values in the liver biopsy specimens of patients who developed hepatocellular carcinoma (mean (SD) value $4.48(1.49) \mu \mathrm{m}^{2}$, range $2 \cdot 55$ to $7 \cdot 42 \mu \mathrm{m}^{2}$ ) were significantly higher than those (mean value $3.00(0.91)$ $\mu \mathrm{m}^{2}$, range 2.01 to $5.02 \mu \mathrm{m}^{2}$ ) in patients without hepatocellular carcinoma (Fisher's exact test: (univariate) odds ratio $7.9 ; 95 \%$ confidence interval $1 \cdot 4-45 \cdot 9 ; \mathrm{p}=0.0255$ ).

We identified two groups of patients according to their mean AgNOR values, using a cutoff value of $3 \mu \mathrm{m}^{2}$ that had already been established as borderline between rapidly and slowly proliferating tissues. ${ }^{10}$ Seventeen cases (group 1) had a mean AgNOR value smaller than $3 \mu \mathrm{m}^{2}$ and the other 16 (group 2) greater than $3 \mu \mathrm{m}^{2}$. Two patients out of $17(11.8 \%)$ of group 1 developed hepatocellular carcinoma compared with nine patients out of $16(56.2 \%)$ in group $2\left(\chi^{2} 4 \cdot 83 ; \mathrm{p}=0.036\right)$.

Figures 1 and 2 show two cases with a different AgNOR number. One patient in group 1 (case 5) with a low AgNOR value showed no evidence of hepatocellular carcinoma 52 months after the diagnosis of cirrhosis (fig 1). One case in group 2 (case 30 ) with a high AgNOR value developed the disease 20 months after cirrhosis had been diagnosed (fig 2).

Variations in AgNOR values were not significantly associated with a different prevalence of cirrhosis and inflammation in the two groups. Cirrhosis was present in nine of 17 group 1 patients and in 10 of 16 group 2 patients; severe inflammation occurred in 13 of 17 and in eight of 16 patients, respectively. Patients with multiple hepatitis infections (two in group 1 and eight in group 2) had higher AgNOR values than patients with single virus infection (14 in group 1 and six in group 2), but this difference was not significant because of the low number of biopsy specimens. Six of seven patients with hepatitis D virus infection (three of which developed hepatocellular carcinoma) had AgNOR values higher than $3 \mu \mathrm{m}^{2}$.

\section{Discussion}

It is well known that the quantity of interphase AgNORs is greater in neoplastic than in corresponding benign or normal tissues. ${ }^{15} 16$ As far as liver pathology is concerned, Crocker and McGovern showed that hepatocellular carcinoma was always characterised by a greater quantity of interphase AgNORs than cirrhotic liver. ${ }^{17}$ In the same study the authors observed that interphase AgNOR numbers in dysplastic cirrhosis fell between those in cirrhosis alone and hepatocellular carcinoma. The quantity of interphase AgNORs is strictly related to cell proliferative activity. ${ }^{15} 16$ AgNOR value increases during $G_{1}$ phase to reach its peak during S-phase..$^{18}$ In proliferating cells the faster the cell proliferation the greater the interphase AgNOR activity. ${ }^{12}$ The results of our study indicate that a high hepatocyte proliferation rate, as measured by high AgNOR numbers in the hepatocyte nuclei of patients with chronic liver disease, is associated with a higher incidence of hepatocellular carcinoma: $82 \%$ of patients who developed cancer had an AgNOR value 
Clinical features of patients and results of AgNOR area detection

\begin{tabular}{|c|c|c|c|c|c|}
\hline Case No & $\begin{array}{l}\text { Age at } \\
\text { biopsy }\end{array}$ & $\begin{array}{l}\text { Aetiology of } \\
\text { liver disease }\end{array}$ & Histology & $\begin{array}{l}\text { Hepatocellular } \\
\text { carcinoma }\end{array}$ & $\begin{array}{l}\text { AgNOR area } \\
\text { (mean }(S D))\end{array}$ \\
\hline \multicolumn{6}{|l|}{ Group 1} \\
\hline 1 & 30 & $\mathrm{HCV}$ & CAH A/cirrhosis/steatosis & No & $2.01(0.50)$ \\
\hline 2 & 35 & HBV & CAH B & No & $2.06(0.54)$ \\
\hline 3 & 54 & $\mathrm{HCV}$ & CAH B & No & $2.12(0.52)$ \\
\hline 4 & 55 & HBV & CAH A/cirrhosis & No & $2 \cdot 21(0.77)$ \\
\hline 5 & 59 & HBV & CAH B/cirrhosis & No & $2.26(0.68)$ \\
\hline 6 & 33 & HBV & CAH B & No & $2.31(0.74)$ \\
\hline 7 & 59 & NANB & CAH B/cirrhosis/steatosis & No & $2.32(0.73)$ \\
\hline 8 & 45 & HBV & CAH B/lobular lesion/steatosis & No & $2.39(0.73)$ \\
\hline 9 & 58 & HBV & CAH A/cirrhosis & No & $2.47(0.77)$ \\
\hline 10 & 28 & $\mathrm{HBV} / \mathrm{HCV}$ & CAH A/steatosis & No & $2.51(0 \cdot 80)$ \\
\hline 11 & 66 & Haemocromatosis & CAH A/siderosis & Yes & $2.55(0.47)$ \\
\hline 12 & 66 & HCV & CAH B & Yes & $2.59(0.63)$ \\
\hline 13 & 53 & HBV & $\mathrm{CAH} \mathrm{A} /$ cirrhosis & No & $2.79(0.75)$ \\
\hline 14 & 55 & HBV & CAH A/cirrhosis & No & $2.85(0.92)$ \\
\hline 15 & 36 & HBV & CAH A/cirrhosis & No & $2.90(0.77)$ \\
\hline 16 & 39 & HBV/HDV & CAH B & No & $2.95(0.84)$ \\
\hline 17 & 58 & HBV & CAH B/cirrhosis & No & $2.96(0.79)$ \\
\hline $\begin{array}{l}\text { Group } 2 \\
18\end{array}$ & & & & & \\
\hline $\begin{array}{l}18 \\
19\end{array}$ & $\begin{array}{l}23 \\
39\end{array}$ & $\begin{array}{l}\mathrm{HBV} / \mathrm{HCV} / \mathrm{HDV} \\
\mathrm{HBV}\end{array}$ & $\begin{array}{l}\text { CAH B/severe lobular lesion/cholestasis } \\
\text { CAH B/cirrhosis/steatosis }\end{array}$ & $\begin{array}{l}\text { Yes } \\
\text { No }\end{array}$ & $\begin{array}{l}3.06(1.04) \\
3.17(1.50)\end{array}$ \\
\hline 20 & 59 & Alcohol & Cirrhosis & Yes & $3.42(1 \cdot 12)$ \\
\hline 21 & 53 & Alcohol & Cirrhosis & Yes & $3.43(1 \cdot 13)$ \\
\hline 22 & 49 & HBV & CAH B/steatosis & No & $3.51(1.40)$ \\
\hline 23 & 65 & $\mathrm{HCV}$ & CAH B/cirrhosis & Yes & $3.83(1.84)$ \\
\hline 24 & 33 & HBV/HDV & CAH B/cirrhosis/steatosis & No & $4 \cdot 14(1 \cdot 89)$ \\
\hline 25 & 42 & HBV/HDV & Suggestive of acute hepatitis & No & $4 \cdot 17(1 \cdot 44)$ \\
\hline 26 & 56 & $\mathrm{HBV} / \mathrm{HDV}$ & CAH B/lobular lesion/steatosis & Yes & $4.51(1.50)$ \\
\hline 27 & 64 & $\mathrm{HCV}$ & CAH B/cirrhosis/severe steatosis & No & $4 \cdot 51(1 \cdot 62)$ \\
\hline 28 & 37 & HBV/HDV & CAH B/cirrhosis & No & $4 \cdot 52(1 \cdot 79)$ \\
\hline 29 & 39 & $\mathrm{HBV} / \mathrm{HCV}$ & CAH B/siderosis & No & $5.02(2.01)$ \\
\hline 30 & 61 & HBV & CAH B/cirrhosis & Yes & $5 \cdot 27(2 \cdot 39)$ \\
\hline 31 & 69 & HBV & CAH A/cirrhosis/steatosis & Yes & $5.46(2.77)$ \\
\hline 32 & 48 & $\mathrm{HBV} / \mathrm{HCV}$ & CAH A & Yes & $5.75(2 \cdot 42)$ \\
\hline 33 & 40 & HBV/HDV & CAH B/cirrhosis & Yes & $7 \cdot 42(4 \cdot 43)$ \\
\hline
\end{tabular}

CAH A chronic active hepatitis with mild or moderate activity; CAH B chronic active hepatitis with severe activity; HBV hepatitis $B$ virus; $H C V$ hepatitis $C$ virus; HDV hepatitis D virus; NANB non- $A$, non-B hepatitis.

greater than $3 \mu \mathrm{m}^{2}$, compared with only $31 \%$ without hepatocellular carcinoma. The proliferation rates observed in patients with multiple hepatitis infections (in particular with hepatitis D superinfection) and with chronic liver lesions are higher than those of patients with just one virus infection, suggesting that hepatitis viruses may have a synergistic role in the deregulation of cell proliferation. These findings are consistent with epidemiological, clinical, and pathological data, indicating that chronic hepatitis D virus infection in patients with chronic liver disease is associated with the development of hepatocellular carcinoma at an early age. ${ }^{19} 20$ This hypothesis prompts further study on a larger number of cases.

In conclusion, AgNOR quantitative analysis can be used to evaluate the hepatocyte proliferation rate in routine sections from small needle biopsy specimens. A cutoff value of $3 \mu \mathrm{m}^{2}$ can represent a valuable parameter to identify patients at high risk of developing hepatocellular carcinoma. Its predictive value has to be confirmed in a larger series of patients.

This work was supported by Grants from MURST ( $40 \%$ and $60 \%$ ), Pallotti's Legacy for Cancer Research, and Regione Emilia-Romagna (DGR 4243/1991). Part of this study was sponsored by the CNR Contract No 92.02300.PF39.

We thank Professor Gioacchino Leandro, Istituto Saverio

De Bellis, Castellana Grotte (BA) for statistical analysis.

1 Zanetti A. Hepatitis B vaccination: an important method of preventing HBV-related hepatocellular carcinoma. Ital f Gastroenterol 1992;24:100-2.

2 Colombo M, De Franchis R, Del Ninno E, et al. Hepatocellular carcinoma in Italian patients with cirrhosis. N Engl f Med 1991;325:675-80.

3 Farber E. Response of the liver to carcinogens. In: Farber E, Fisher M, eds. Injury of the liver. Part A. New York: Marcel Dekker 1979:445-6.

4 Tanaka T, Tacheuchi T, Nisikawa A, Takami T, Mori H.
Nucleolar organizer regions in hepatocarcinogenesis induced by $\mathrm{N}-2$-Fluorenylacetamide in rats: comparison with bromodeoxyuridine immunoistochemistry. Ipn $\mathcal{f}$ Cancer Res 1989;80:1047-51.

5 Hernandez-Verdun $D$. The nucleolar organizer regions. Biol Cell 1986;49:191-202.

6 Derenzini M, Thiry M, Goessens G. Ultrastructural Cytochemistry of the mammalian cell nucleolus. $f$ Histochem Cytochem 1990;38:1237-56.

7 Crocker J, Macartney JC, Smith PJ. Correlation between DNA flow cytometric and nucleolar organizer regions in non-Hodgkin's lymphoma. $\mathcal{f}$ Pathol 1988;154:151-6.

8 Giri DD, Nottingham JF, Lawry J, Dundas SAC, Underwood JC. Silver binding nucleolar organizer regions (Ag-NORs) in benign and malignant breast lesions: correlation with ploidy and growth phase by DNA flow cytometry. $₹$ Pathol 1989;157:307-13.

9 Orita T, Kajiwara K, Nishizaki T, Ikeda N, Kamiryo T, Aoki $\mathrm{H}$. Nucleolar organizer regions in meningioma. Neurosurgery 1990;26:43-6.

10 Trerè D, Farabegoli F, Cancellieri A, Ceccarelli C, Eusebi V, Derenzini M. Ag-NOR protein quantity in human tumors correlates with the proliferative activity evaluated by bromodeoxyuridine labeling and $\mathrm{Ki} 67$ immunostaining. F Pathol 1991;165:53-9.

11 Trerè $D$, Pession A, Derenzini $M$. The silver-stained proteins of interphasic nucleolar organizer regions as a parameter of cell duplication rate. Exp Cell Res 1989; 184:131-7.

12 Derenzini $M$, Pession $A$, Trerè $D$. The quantity of nucleolar silver-stained proteins is related to proliferating activity in cancer cells. Lab Invest 1990;63:137-40.

13 Knodell RG, Ishak KG, Black WC, et al. Formulation and application of a numerical scoring system for assessing histological activity in asymptomatic chronic active hepatitis. Hepatology 1981;1:431-5.

14 Ploton D, Menager M, Jeannesson P, Himber G, Pigeon $F$, Adnet JJ. Improvement in the staining and in the visualization of the argyrophilic proteins of the nucleolar organizer region at the optical level. Histochem $\mathcal{F} 1986$; 18:5-14.

15 Crocker J. Nucleolar organizer regions. Curr Top Pathol 1990;82:91-149.

16 Derenzini $M$, Trerè $D$. Importance of interphase Nucleolar organizer regions in tumor pathology. Virchows Arch (Cell Pathol) 1991;61:1-8.

17 Crocker J, McGovern J. Nucleolar organizer regions in normal, cirrhotic and carcinomatous livers. $\mathcal{F}$ Clin Patho 1988;41:1044-8.

18 Pession A, Farabegoli F, Treré D, et al. The Ag-NOR proteins and transcription and duplication of ribosoma genes in mammalian cell nucleoli. Chromosoma 1991 100:242-50.

19 Oliveri F, Brunetto MR, Actis GC, Bonino F Pathobiology of chronic hepatitis virus infection and hepatocellular carcinoma (HCC). Ital f Gastroenterol 1991;23:498-502.

20 Verme G, Brunetto MR, Oliveri F, et al. Role of hepatitis delta virus infection in hepatocellular carcinoma. Dig Dis Sci 1991;36:1134-6. 